\title{
The Global Network of Isotopes in Rivers (GNIR): integration of water isotopes in watershed observation and riverine research
}

\author{
J. Halder, S. Terzer, L. I. Wassenaar, L. J. Araguás-Araguás, and P. K. Aggarwal \\ Isotope Hydrology Section, International Atomic Energy Agency, 1400 Vienna, Austria \\ Correspondence to: J. Halder (j.halder@iaea.org) \\ Received: 18 March 2015 - Published in Hydrol. Earth Syst. Sci. Discuss.: 22 April 2015 \\ Revised: 8 July 2015 - Accepted: 24 July 2015 - Published: 5 August 2015
}

\begin{abstract}
We introduce a new online global database of riverine water stable isotopes (Global Network of Isotopes in Rivers, GNIR) and evaluate its longer-term data holdings. Overall, 218 GNIR river stations were clustered into three different groups based on the seasonal variation in their isotopic composition, which was closely coupled to precipitation and snowmelt water runoff regimes. Sinusoidal fit functions revealed phases within each grouping and deviations from the sinusoidal functions revealed important river alterations or hydrological processes in these watersheds. The seasonal isotopic amplitude of $\delta^{18} \mathrm{O}$ in rivers averaged $2.5 \%$, and did not increase as a function of latitude, like it does for global precipitation. Low seasonal isotopic amplitudes in rivers suggest the prevalence of mixing and storage such as occurs via lakes, reservoirs, and groundwater. The application of a catchment-constrained regionalized cluster-based water isotope prediction model (CC-RCWIP) allowed for direct comparison between the expected isotopic compositions for the upstream catchment precipitation with the measured isotopic composition of river discharge at observation stations. The catchment-constrained model revealed a strong global isotopic correlation between average rainfall and river discharge $\left(R^{2}=0.88\right)$ and the study demonstrated that the seasonal isotopic composition and variation of river water can be predicted. Deviations in data from model-predicted values suggest there are important natural or anthropogenic catchment processes like evaporation, damming, and water storage in the upstream catchment.
\end{abstract}

\section{Introduction}

Rivers play a crucial role in earth's water cycle as watershedintegrating hydrological conduits for returning terrestrial precipitation back to the world's oceans. Despite comprising less than $0.1 \%$ of the world's available surface freshwater, rivers are commonly linked to the largest freshwater reserves, like permafrost, glaciers, aquifers, as well as lake and wetland systems (e.g. Oki and Kanae, 2006). Recent estimates suggest that there are more than 58000 dams sited on the world's rivers (ICOLD, 2015), with very few rivers left in a state of natural discharge regime (Dynesius and Nilsson, 1994). Riverine water quality degradation may be manifested by increasing downstream water pollution (chemicals that impact human consumption or recreational use), nutrient loadings, sedimentation, altered aquatic ecosystem function, or loss of biodiversity, and cultural eutrophication of estuarine and marine receiving environments (e.g. Gulf of Mexico "dead zone"). A survey of global rivers revealed a state of moderate to high threat, with little evidence for turnaround with an ever increasing population and rising water demands (Vörösmarty et al., 2010). Furthermore, owing to the fact that many important large rivers are transboundary, these threats have the potential to lead to conflict around freshwater security issues.

At any point along a river reach, water is ultimately derived from precipitation falling within its upstream catchment area. Depending on the size (ranging from a few square kilometres to $>5$ million $\mathrm{km}^{2}$ ) and geomorphological characteristics of the catchment, a variety of hydrological processes may affect the catchment and river water flow. The stable isotope ratios of the water molecule $\left({ }^{18} \mathrm{O} /{ }^{16} \mathrm{O},{ }^{2} \mathrm{H} /{ }^{1} \mathrm{H}\right)$ are well-established powerful integrative recorders of key catchment processes (evaporation and transpiration, recy- 
cling, mixing) and catchment water balance, as well as tracers of river recharge sources (direct precipitation, runoff, soil water, groundwater, lakes, snow and ice) (e.g. McDonnell et al., 1990; Kendall and McDonnell, 1998; Lambs, 2000; Gibson et al., 2005; Liu et al., 2008; Jasechko et al., 2013). Hydrological processes occurring between rainfall input and river discharge modify the stable isotopic composition of rivers and include the isotopic averaging during soil infiltration, runoff, damming (Ogrinc et al., 2008; Koeniger et al., 2009) and seasonally differential fractional inputs of water from surface and groundwater sources (Sklash, 1990; Buttle, 1994; Lambs, 2004); and heavy isotope $\left({ }^{2} \mathrm{H},{ }^{18} \mathrm{O}\right)$ enrichment due to the effects of watershed evapotranspiration or instream evaporation (Simpson and Herczeg, 1991; Gremillion and Wanielista, 2000; Telmer and Veizer, 2000) and isotopic fractionation of snowmelt (Taylor et al., 2002). All of these processes may result in markedly different average isotopic values in river discharge compared to precipitation, both in space and time (Dutton et al., 2005; Rock and Mayer, 2007).

Generally, a review of the literature reveals that longitudinal $\delta^{18} \mathrm{O}$ and $\delta^{2} \mathrm{H}$ variations in a river strongly depend on the catchment elevation, since headwaters at high altitudes are generally depleted in ${ }^{18} \mathrm{O}$ and ${ }^{2} \mathrm{H}$ compared to lower elevation downstream regions (e.g. Longinelli and Edmond, 1983; Ramesh and Sarin, 1992; Pawellek et al., 2002; Winston and Criss, 2003; Rock and Mayer, 2007), except where high altitude tributaries merge into low elevation main stems (Yang et al., 1996; Yi et al., 2010). The cumulative effect of catchment-scale evapotranspiration and instream evaporative processes may additionally increase $\delta^{18} \mathrm{O}$ and $\delta^{2} \mathrm{H}$ values in the downstream direction. Rivers that are hundreds of kilometres long may therefore have distinctive upstream versus downstream isotopic patterns as they accumulate discharge and integrate various hydrological processes from contributing subcatchments (Simpson and Herczeg, 1991; Gremillion and Wanielista, 2000; Ferguson et al., 2007; Bowen et al., 2011). Alpine or high-latitude rivers may be ephemeral, dominated mostly by isotopically depleted snowmelt events (e.g. Friedman et al., 1992; Meier et al., 2013). Seasonal isotopic variations in rivers, nevertheless, can mirror annual variations in precipitation (e.g. Dalai et al., 2002; Lambs et al., 2005), but these variations are usually moderate compared to precipitation as a result of catchment buffering and the fact that the predominant source of riverine baseflow often stems from relatively isotopically stable groundwater sources (Darling and Bath, 1988; Maloszewski et al., 1992; Kendall and Coplen, 2001; Dutton et al., 2005). Only a few systematic long time series ( $>5$ years) of monthly isotope sampling of rivers have ever been published. Those few which have been presented in detail (e.g. Danube River, Austria, 47 years; Swiss and German rivers, 30-36 years; Paraná River, Argentina, 5 years) show great potential for identifying long-term hydrologic alterations and providing key scientific information for water resource assessments, since longterm isotope river data must ultimately record climatic trends and human impacts within a watershed. In particular, differences in the timing and mixing of winter and summer precipitation runoff are observed in the variation of the river isotopic values over time. Moreover, dry and wet seasons as well as extreme precipitation events (Schotterer, 2010) or atmospheric oscillation cycles as the El Niño-Southern Oscillation (ENSO) (Panarello and Dapeña, 2009) are revealed in riverine isotope records. In alpine catchments, the intensity and extension of hydropower reservoirs show important impacts on the natural seasonal isotopic amplitude, indicating for example the fluctuating mixing ratios of water sources due to reservoir storage and release (Rank et al., 1998, 2014; Schotterer, 2010). Long-term patterns of isotopes in rivers generally correlate with that of local precipitation; however, the catchment signals may be delayed up to several years (Rank et al., 2014), or differ for rivers within a geographical region (Schotterer, 2010; Stumpp et al., 2015). Hence, long-term riverine isotopic time series are key to providing scientific information for water managers and researchers to gain insights to study hydrological processes and better focus integrated water management strategies.

The isotopic composition of precipitation has been monitored for over 50 years worldwide through the Global Network of Isotopes in Precipitation (GNIP), a joint initiative of the International Atomic Energy Agency (IAEA), the World Meteorological Organization (WMO), and collaborating institutions as well as individuals (Rozanski et al., 1993; Aggarwal et al., 2010; IAEA/WMO, 2015). In order to fill isotopic data gaps between the well-known continental precipitation inputs to terrestrial landscapes and the aggregated and altered riverine discharges to the sea, a new Global Network of Isotopes in Rivers (GNIR) was initiated as part of the IAEA Water Resources Programme. GNIR began as a pilot project in 2002-2005 and focussed on the stable isotopes and tritium content of various world river catchments (Vitvar et al., 2007; Michel et al., 2014). The aim of the GNIR programme is to collect and disseminate time-series and synoptic collections of riverine isotope data from the world's rivers and to inform a range of scientific disciplines including hydrology, meteorology and climatology, oceanography, limnology, and aquatic ecology.

The objective of this paper is twofold: first, we formally introduce a new online database of riverine isotopes as the GNIR, a publicly accessible database found at https: //nucleus.iaea.org/wiser. Second, having pre-populated the GNIR database with pilot, volunteered, and literature riverine isotopic data; we provide a first effort to analyse the spatial and isotopic patterns of GNIR sampling sites that are comprised of longer data series for $\delta^{18} \mathrm{O}$ and $\delta^{2} \mathrm{H}$. This assessment provides a first-order global-scale perspective regarding (i) seasonal (variation of monthly mean values) and local variations of the isotopic composition of river waters (ii) and helps to assess the comparative correlations and connectivity between the global isotopic variance in precipitation and that of river discharge. It was assumed that the seasonal and local 
variation of the isotopic composition of river water would be closely coupled to the isotopic variance in precipitation.

Our meta-analyses provide a first overview of the potential for water stable isotopes to identify large-scale hydrologic processes in global rivers and to prove its application. With recent developments in low-cost laser spectroscopy techniques for conducting water isotope analysis, the widespread adoption of stable isotope tracers is now achievable in many national river water quality monitoring programs (Kendall et al., 2010) as well as in aquatic ecological studies. We aim to demonstrate the benefits of routinely applying water stable isotopes as key tracers in evaluating hydrological processes in the worlds' rivers and for the observation of short- as well as long-term climatic and human impacts.

\section{Materials and methods}

\subsection{The GNIR database}

The GNIR relies upon voluntary partnerships with institutions and researchers for riverine sample collections and isotopic analyses, as well as upon contributions of published and unpublished data to the GNIR online database. The GNIR database comprises an electronic repository holding river water isotope and associated geographical and physiochemical parameters, and was recently extended to include important water-quality-related isotopic parameters as well as other riverine isotopes. GNIR is publicly accessible online through the web-based Water Isotope System for Data Analysis, Visualization and Electronic Retrieval (WISER) interface at https://nucleus.iaea.org/wiser. The GNIR database is structured as a relational database allowing for queries on a number of attributes, particularly on spatial and temporal attributes. All data for GNIP and GNIR can be downloaded in CSV or Microsoft Excel ${ }^{\circledR}$ flat files, cost free to registered users. For the inclusion of additional stations and technical details regarding GNIR catchment sampling, data structure, and quality assessment of data, the reader is referred to the IAEA website (http://www.iaea.org/water).

\subsection{Water isotope reporting}

Stable isotopic compositions of river water samples were measured at the Isotope Hydrology Laboratory of the IAEA and a large number of external laboratories. Not all of the methodological procedures and metadata were recorded in the past; hence, the reported analytical uncertainties for $\delta^{2} \mathrm{H}$ and $\delta^{18} \mathrm{O}$ were not always available. Because water samples were analysed at so many different laboratories, using different analytical methods over many years, the analytical error can be assumed to be on the order of $\pm 0.2 \%$ for $\delta^{18} \mathrm{O}$ and $\pm 2.0 \%$ for $\delta^{2} \mathrm{H}$. Nevertheless, all stable isotope measurements are expressed as $\delta$ value relative isotope-ratio differences, defined by the equation $\delta X=\left[\left(R_{\mathrm{A}} / R_{\mathrm{std}}\right)-1\right]$,

where $R_{\mathrm{A}}$ and $R_{\text {std }}$ are the isotope ratios of the heavier and lighter isotopes of the element $X$ (e.g. ${ }^{2} \mathrm{H} /{ }^{1} \mathrm{H},{ }^{18} \mathrm{O} /{ }^{16} \mathrm{O}$ ) in the sample and the international standard (Vienna Standard Mean Ocean Water, VSMOW), respectively. All water isotope $\delta$ values are reported in parts per thousand (\%o) deviations from the international VSMOW standard.

\subsection{Seasonal and local variations in the isotopic composition in river waters}

We extracted and tabulated $\delta^{18} \mathrm{O}\left(\delta^{2} \mathrm{H}\right.$ is strongly correlated but less frequently measured historically) isotope data for river stations having close to 2 years of monthly time series data (minimum five samples per year), or 1-2 years for geographical regions having poor spatial data coverage (e.g. South America, Africa, and Asia). The river water isotopic data evaluated were measured between 1960 and 2012. A map of all long-term GNIR sampling sites and a complete data table, including reference list, of the selected GNIR stations used in this study are shown in the Supporting Information.

All river time series stable isotope data were averaged to depict monthly mean values (not discharge weighted due to missing flux data) over the measured time period. The selected GNIR station data were clustered by the timing of minimum $\delta^{18} \mathrm{O}$ values and latitude, according to the flowchart in Fig. 1. It was assumed that seasonal and local variations of the isotopic composition of river water were closely coupled to the well-understood regional and continental isotopic variance in precipitation (Rozanski et al., 1982, 1993, 1996; Araguás-Araguás et al., 1998; Bowen and Wilkinson, 2001; Feng et al., 2009). The first aim, however, was to isotopically distinguish snow- and glacier-runoff-dominated systems from direct precipitation- and runoff-dominated systems. Rivers were then grouped by $\delta^{18} \mathrm{O}$ minima in late spring and summer due to delayed seasonal snow- and glacier melt at higher altitudes (e.g. Meier et al., 2013). A second grouping was clustered by higher latitudes $\left(>30^{\circ}\right.$ latitude) and $\delta^{18} \mathrm{O}$ minima in the winter months during the lowest air temperature (Dansgaard, 1964). The last group comprised GNIR stations within a $30^{\circ} \mathrm{N} / \mathrm{S}$ latitude band. Those were filtered based on the phase difference between the two low-latitude zones (N-S), which was about six months, according to Feng et al. (2009). The variation of the isotopic composition of tropical precipitation between $\sim 30^{\circ} \mathrm{N}$ and $30^{\circ} \mathrm{S}$ was determined by air temperature and by atmospheric circulation as the inter-tropical convergence zone (ITCZ) (e.g. Yoshimura et al., 2003). Consequently, a best-fit model of the 6-month-phase difference (January-June and JuneDecember) was used. After clustering, a least-squares fitted sinusoidal function was applied to evaluate the periodicity of the $\delta^{18} \mathrm{O}$ variations for all groups using the equation 


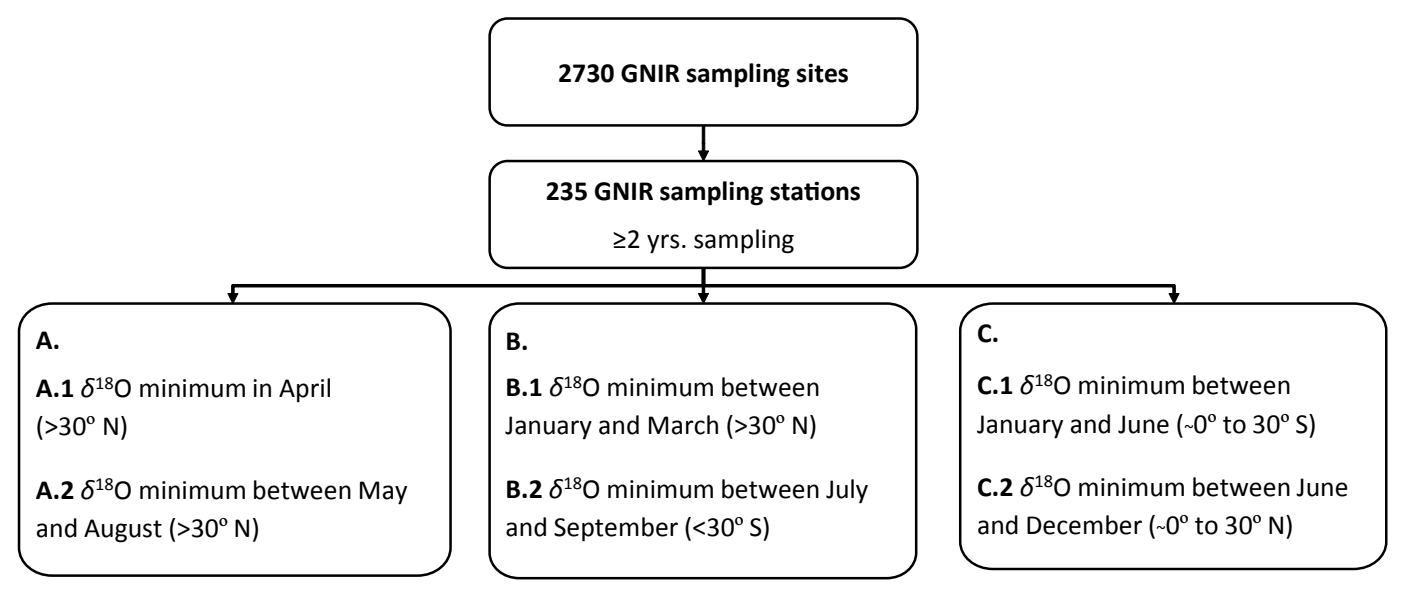

Figure 1. Flowchart of river grouping. The diagram illustrates the criteria used to cluster long-term GNIR stations ( $>2$ years) into three major groups and three subgroups, based on their stable isotopic patterns.

$\hat{\delta}^{18} O=A[\sin (2 \pi t+\Theta)]$,

where $A$ is amplitude, $t$ is lag time in years, and $\Theta$ is phase angle.

\subsection{Comparing the isotopic compositions of world rivers to precipitation}

To compare the variance of $\delta^{18} \mathrm{O}$ in river water to precipitation, riverine isotopic seasonality was compared with precipitation isotope data. GNIR stations that were obviously snowand glacier-runoff-dominated were excluded from this comparison, in order to compare the direct relationship between precipitation and river runoff. Feng et al. (2009) evaluated selected GNIP precipitation data using a similar approach; however, in the present study we used GNIP data updated to 2013. Subsequently, 567 GNIP and 218 GNIR stations with averaged (amount-weighted for GNIP) monthly $\delta^{18} \mathrm{O}$ values were used for a direct comparison.

One major challenge comparing terrestrial rainfall inputs with point-based river isotope locations was the fact there were usually few GNIP stations distributed across watersheds, and they were rarely in locations that may be considered representative of all precipitation in a watershed. Some have proposed mathematical models to derive the comparability of the isotopic composition of rivers to rainfall, but these models rely on discrete but sparsely distributed GNIP station data or were applied regionally (Landwehr and Coplen, 2006; Bowen et al., 2011). To overcome this GNIP coverage limitation, we used a catchment-constrained version of the regionalized cluster-based water isotope prediction (RCWIP) model based on GNIP data (Terzer et al., 2013). This catchment constrained model modification (CCRCWIP) was used to estimate the average amount-weighted isotopic composition of rainfall in the upstream catchment of a selected GNIR station. The upstream catchment delineations were taken from the HYDRO1K basins geospatial data set (data available from the US Geological Survey). Unfortunately, the application of the method was restricted by the resolution of the RCWIP grid (cell size of $10 \mathrm{arcmin}$, ca. $20 \mathrm{~km}$ at the Equator). As a minimum, albeit arbitrary threshold catchment size, we defined $500 \mathrm{~km}^{2}$ or $\geq 4$ grid cells. The $\delta^{18} \mathrm{O}$ values for catchment-constrained precipitation were calculated as the amount-weighted mean of all RCWIP grid cells falling within the upstream catchment boundary polygon of a GNIR station, after predetermining basin membership by spatial selection (ArcGIS 10.2.2, ESRI, Redlands, CA), on a monthly or annual basis. The model error for derived $\delta^{18} \mathrm{O}$ catchment precipitation input values was on average $\pm 1.1 \%$. In total, the CC-RCWIP method was successfully applied to 119 GNIR stations and catchments. The detailed results are tabulated in the Supplement. Data for the detailed subcatchment studies were kindly provided by the Helmholtz-Zentrum Munich, Germany; Environment Agency Austria; Federal Office for the Environment, Switzerland; and Centre for Isotope Research, University of Groningen, the Netherlands.

\section{Results and discussion}

\subsection{GNIR water stable isotope data holdings}

Currently, the GNIR database contains about 2730 sampling sites for water stable isotopes from 56 countries, covering all continents. The GNIR database covers rivers of all lengths and sizes, including lakes and reservoirs falling within the course of rivers. A review of the GNIR data holdings showed that most of the sampling sites were a part of longitudinal or synoptic river studies, since 2000 out of the 2730 GNIR sampling sites recorded only one water isotope sample taken (Fig. 2). The evaluation showed also that most published isotopic river studies were generally focussed on smaller regional catchments or subcatchments of national or regional 


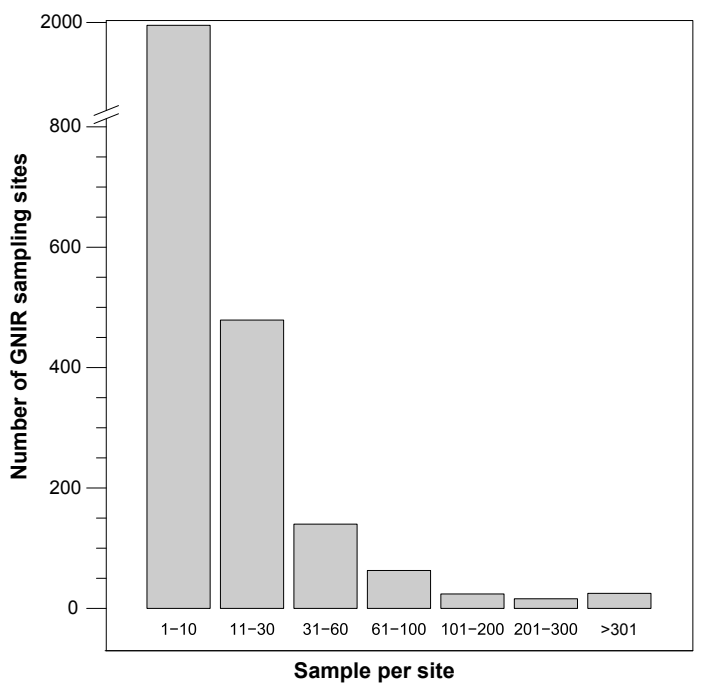

Figure 2. GNIR station and sample statistics. Frequency histogram of GNIR sampling sites ( $y$ axis) (1960-2012) and the number of water isotope samples per sampling site ( $x$ axis).

interest, either as one-time synoptic surveys, or as one-point measurements in larger watersheds. Fewer still, were integrated riverine isotopic studies aimed at quantifying major catchment-scale processes, including targeted sampling across all hydrograph stages (and under ice). For the few remaining large-scale isotopic studies, sampling locations were often opportunistically based upon existing water quality monitoring programs, river access, or are one-time efforts and therefore less informed by hydrological considerations (Kendall and Coplen, 2001; Hélie and Hillaire-Marcel, 2006; Ferguson et al., 2007). Rarer yet were riverine isotopic studies that extended beyond a 1-2 year effort, across major geopolitical boundaries, or those involving a larger suite of isotopic assays (Kendall et al., 2010). However, 235 GNIR stations had $\geq 2$ years of systematic sampling records. Most of the isotope studies in GNIR did not include additional parameters such as discharge, water temperature, electrical conductivity or other water chemistry.

\subsection{Seasonal and local patterns of $\delta^{18} \mathrm{O}$ in global rivers}

The 235 GNIR river stations could be clustered into three major groupings on the basis of the seasonal variations in their oxygen (or hydrogen) isotopic composition (Fig. 3). Sinusoidal best fit functions (Fig. 3, Supplement) revealed periodic phases within each of these groupings and their subgroups. Because most GNIR stations happened to be located in latitudes above $30^{\circ} \mathrm{N}$, and mainly in central and northern Europe as well as North America, the largest river grouping was comprised of winter snowmelt dominated systems. This group (A) could be further divided into two subgroups; subgroup (A.1) included river stations which were most ${ }^{18} \mathrm{O}$ depleted circa April, which suggested winter precipitation
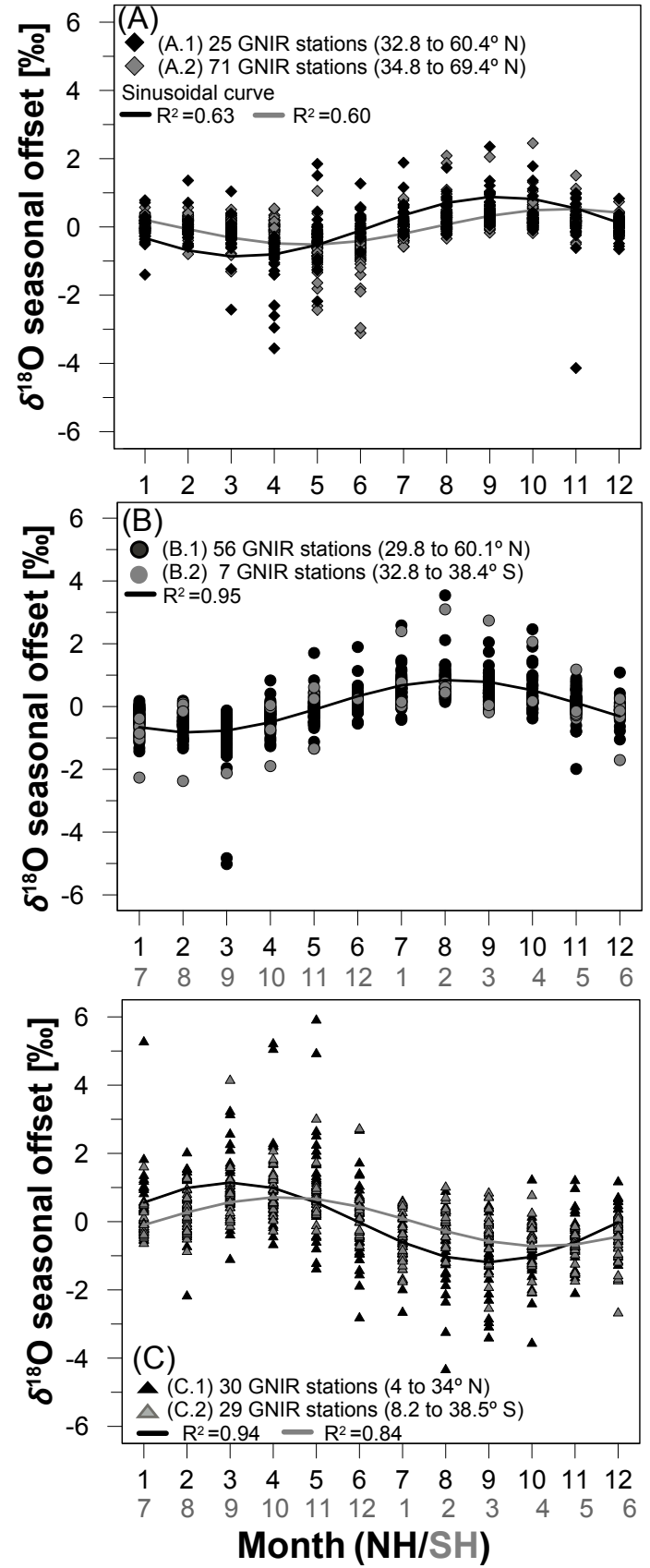

Figure 3. Seasonality of $\delta^{18} \mathrm{O}$ in different river systems. Seasonality clustering, based on the isotopic data, showed that stations could be divided into three major groups and three subgroups. To normalize $\delta^{18} \mathrm{O}$ values, the seasonal variations were plotted as the offset from the mean annual value $(0 \%$ ) for each station. A sinusoidal fit function was applied to the river stations within each subgroup. No sinusoidal curve was calculated for the small group (B.2).

runs off as the spring freshet. These river stations were generally located in lowlands with seasonal winter snow cover, or in peri-alpine headwaters. The second subgroup (A.2) included river stations that were most depleted in ${ }^{18} \mathrm{O}$ between 


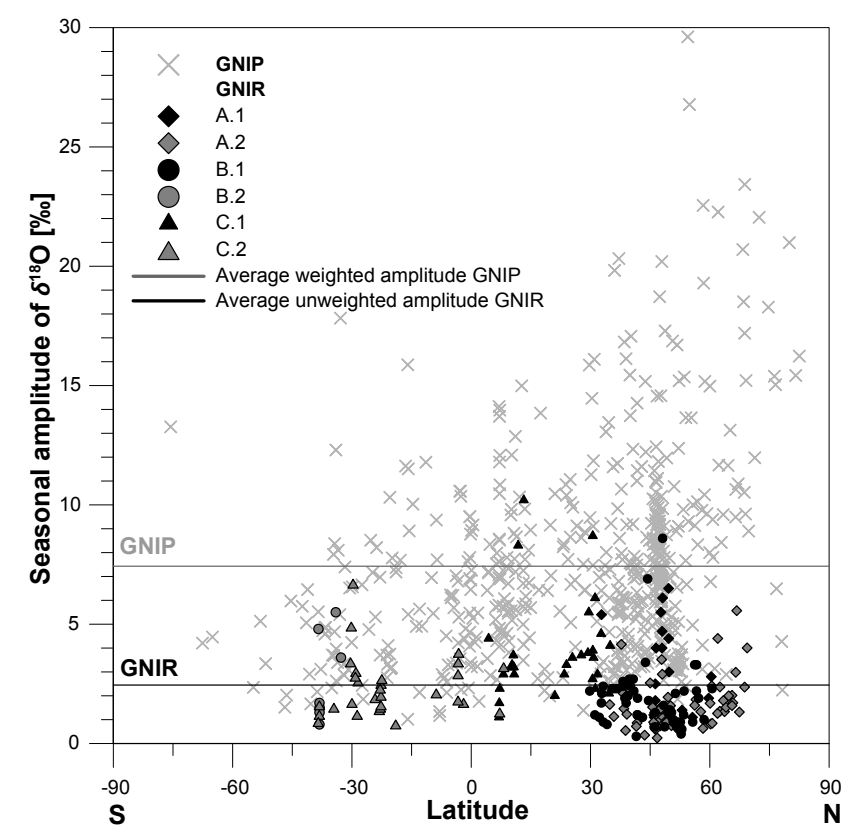

Figure 4. Seasonal amplitude of $\delta^{18} \mathrm{O}$ in rivers. The seasonal isotopic amplitude, expressed as the difference of the highest and lowest monthly mean value against the latitude of the river station for GNIR river groups (diamond, circle and triangle symbols) and for precipitation (GNIP, cross symbol).

May and August, which indicated that infiltration and transport of winter precipitation to rivers was considerably delayed. These river stations were those with primarily alpine and montane headwaters, or were located in Arctic regions. Subgroup (A.2) had, on average, the lowest seasonal $\delta^{18} \mathrm{O}$ amplitude of $1.4 \%$ (expressed as the difference of the highest and lowest monthly mean value; Fig. 4), which may be related to the fact that many of the alpine rivers sampled have discharge-controlled reservoirs or lakes in their headwater catchments. Thus, seasonal variations were diminished by reservoir storage and mixing. For example, the lowest seasonal amplitude in $\delta^{18} \mathrm{O}(0.2 \%)$ of all GNIR stations was observed in the Aare River at Thun, Switzerland, a river in an alpine catchment where the sampling station was located following the outlet of a lake system. Moreover, snowmelt- and glacier-meltwater-dominated contributions with relatively negative $\delta^{18} \mathrm{O}$ values, mixing with enriched summer precipitation, can also suppress seasonal isotope amplitudes. This may explain why river stations whose hydrographs were dominated by early snowmelt, by comparison, had on average higher seasonal amplitudes in $\delta^{18} \mathrm{O}$ on the order of $2.0 \%$. Therefore, it can be stated that low to negligible seasonal isotopic amplitudes in rivers did not necessarily mean that isotopically invariant groundwater baseflow contribution was a predominant source of discharge, as is often assumed.
The second group (B) (Fig. 3) included river stations that closely charted the seasonal temperature curve of the higher latitudes of the Northern Hemisphere (NH, B.1) and Southern Hemisphere (SH, B.2) and, along with that, the seasonal variation of the isotopic composition of precipitation. This subgroup showed the importance of direct surface-runoff and/or fractions of infiltrated water with relatively short residence times as groundwater. However, GNIR river stations of the temperate and higher latitudes without stored winter precipitation in spring or summer had relatively low seasonal amplitudes in $\delta^{18} \mathrm{O}$ on the order of $1.9 \%$ (Fig. 4), indicating also important groundwater baseflow contributions with well-mixed summer and winter precipitation.

Finally, stations located between $\sim 30^{\circ} \mathrm{N}$ and $30^{\circ} \mathrm{S}$, group (C; Fig. 3), could be divided into two subgroups, (C.1) and (C.2), based on a 6-month isotope-phase deviation. In general, these river stations followed not only air temperature but also the phase of atmospheric moisture cycling which was co-determining the isotopic composition of precipitation in those latitudes (Feng et al., 2009, and references there within). In comparison to groups A and B, GNIR stations between $\sim 0^{\circ}$ and $30^{\circ} \mathrm{N}(\mathrm{C} .1)$ had the highest average seasonal isotopic amplitudes for $\delta^{18} \mathrm{O}$ on the order of $3.9 \%$. Therefore, secondary processes increased the isotopic enrichment and depletion and this could be attributed to the fact that these catchments were strongly influenced by pronounced dry and wet seasons. For example, the highest seasonal isotopic amplitude in $\delta^{18} \mathrm{O}(10.2 \%$ ) was observed in the Bani River at Douna, Mali. The highest $\delta^{18} \mathrm{O}$ values in the Bani River corresponded to the end of the dry season in May with extremely low flow, indicating enhanced enrichment in ${ }^{18} \mathrm{O}$ due to in-stream and watershed evaporation. Conversely, the lowest $\delta^{18} \mathrm{O}$ value was observed in the Bani River in August and corresponded to the beginning of the rainy season and movement of the ITCZ. Relatively negative $\delta^{18} \mathrm{O}$ values in river water in this zone correlated with rainy seasons, since rainfall from air mass circulation of the ITCZ are typically more depleted in ${ }^{18} \mathrm{O}$ (e.g. Feng et al., 2009), and the high proportion of direct surface runoff did not allow for isotopic averaging through the soils and baseflow. GNIR stations located between $\sim 0^{\circ}$ and $30^{\circ} \mathrm{S}$ had somewhat lower seasonal amplitudes in $\delta^{18} \mathrm{O}$ on the order of $2.4 \%$; however, this may be spatially biased since this grouping contained more stations in South America, where the dry and wet seasons were less pronounced.

Some GNIR river systems could be assigned to several of the previous groupings, depending on the location of the river station within a larger catchment and the type of hydrological alterations occurring within that watershed, hydrograph stage, and the sampling season. However, some GNIR stations showed seasonal isotopic variations that were typical of headwater latitudes, but not the latitude of the downstream sampling station (e.g. Paraná River, Argentina). Stations in highland headwaters versus downstream reaches may not reflect the same time period (due to time of travel delays). In 

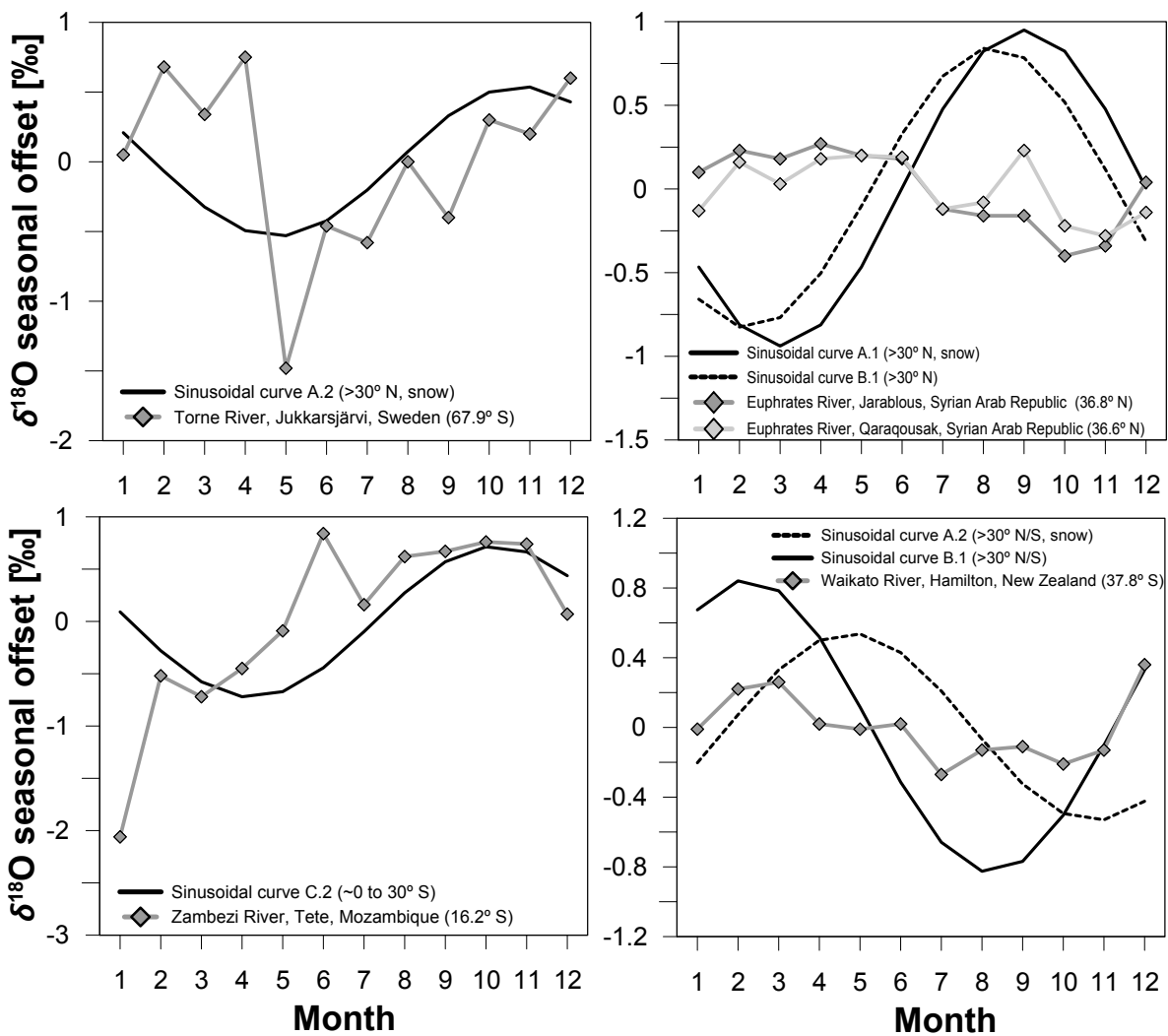

$\begin{array}{lllllllllllll}1 & 2 & 3 & 4 & 5 & 6 & 7 & 8 & 9 & 10 & 11 & 12\end{array}$

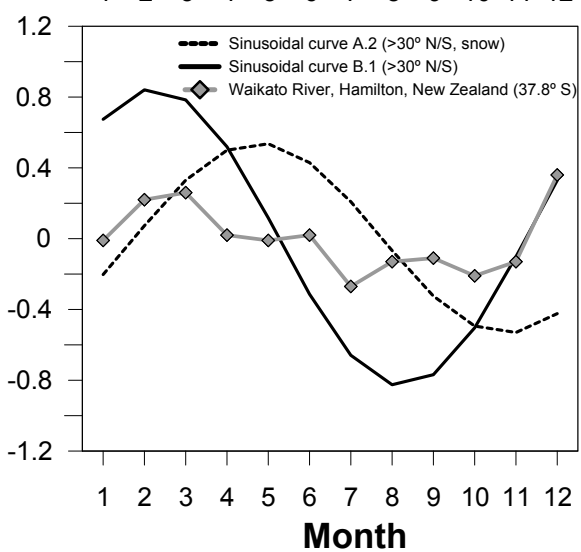

Figure 5. Seasonality of $\delta^{18} \mathrm{O}$ in reservoir-influenced river systems. Hydrologic alterations and natural lakes affected the predicted seasonality of $\delta^{18} \mathrm{O}$ in different river systems. The figure shows examples of GNIR stations for which seasonality of $\delta^{18} \mathrm{O}$ deviated significantly from the sinusoidal curve expected based upon the station's latitude and topography. Case study data were taken from Burgman et al. (1981) (Torne River), Kattan (2012) (Euphrates River), Talma et al. (2012) (Zambezi River), and Mook (1982) (Waikato River).

some cases, the seasonal variation in $\delta^{18} \mathrm{O}$ at downstream stations could be influenced by tributaries having a vastly different water history or isotopic composition than the main stem (e.g. mid-reach Danube River in Austria; Rank et al., 1998 , 2014, or where upstream damming had altered natural runoff patterns, e.g. Oldman River, Canada; Rock and Mayer, 2007). Only 17 of the 235 GNIR stations examined could not be classified into one of these three riverine isotopic groupings. These included river stations located beyond the outlet of large natural lakes or artificial reservoirs.

The results showed that the deviations of $\delta^{18} \mathrm{O}$ values from the model sinusoidal curves (Fig. 5) gave insights into important river alterations and processes, e.g. the freezing of upstream surface water, which changes the river runoff components in winter (e.g. Torne River downstream of Lake Torneträsk, Sweden; Burgman et al., 1981); the averaging of different water sources due to cumulative dam systems (e.g. Euphrates River, Syria; Kattan, 2012, and Waikato River, New Zealand; Mook, 1982); and the mixing of evaporated water and reverse seasonal flow from the outflow of regulated reservoirs having long water residence times (e.g. Zambezi River downstream of Cahora Bassa Dam, Mozambique; Talma et al., 2012).
Despite all of the above caveats, most rivers still reflected the seasonal variation of $\delta^{18} \mathrm{O}$ values in precipitation that was expected based on the topography and latitude of the river basin, even though nearly all of the worlds' rivers flowed through some form of artificial or natural reservoir. Because the GNIR data consisted only of monthly averaged $\delta^{18} \mathrm{O}$ values, and most stations had no discharge data, it could be surmised that a monthly grab sampling approach is likely the minimum sufficient to isotopically characterize a watershed and to record long-term changes in hydrological processes within the watershed over time. The sinusoidal model curves may help to compare and validate measured isotopic compositions of any seasonal river case study. Even if the isotopic composition and variability of a selected river were unknown, the model curves could allow one to predict the seasonal variation of $\delta^{18} \mathrm{O}$ in river water. As isotopic peaks might also be related to stochastic or climatic events such as flooding or atmospheric circulation (e.g. movement of the ITCZ or ENSO), valuable information may also be gained by scheduling targeted higher frequency campaigns (e.g. Berman et al., 2009; Wyhlidal et al., 2014) especially during extreme periods. In addition, the minima and maxima of river isotopic values may help to apply water isotopes 


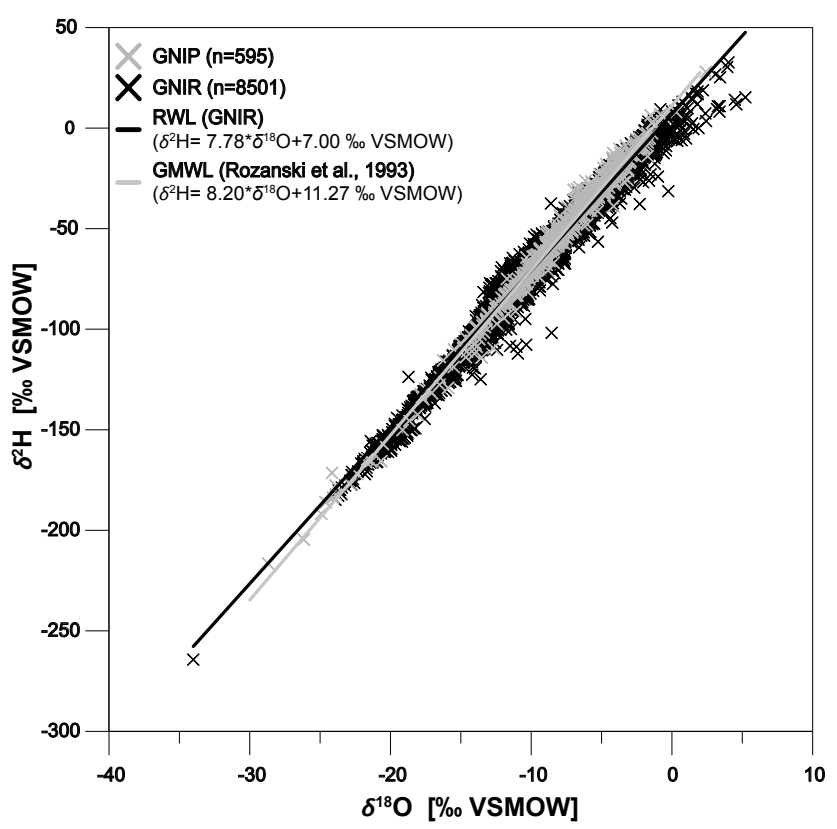

Figure 6. GNIR vs. GNIP. Comparison of all available GNIR water samples (unweighted, grey crosses) and amount-weighted average GNIP data (black crosses).

as tracers to study the infiltration of river water into isotopically averaged groundwater, and local case studies may be conducted during such predicted isotopic peaks.

\subsection{Comparison of water stable isotopes in precipitation and rivers}

A $\delta^{18} \mathrm{O}$ vs. $\delta^{2} \mathrm{H}$ diagram (Fig. 6) comparing GNIP data (mean and amount-weighted isotopic values) and GNIR samples (not averaged or discharge weighted) showed that precipitation and river samples all lie along one global meteoric water line that is well established for water isotopes (Craig, 1961). Although there was no coherent correlation, the seasonal amplitude of $\delta^{18} \mathrm{O}$ in global rivers did not increase with latitude, as in the average observed for precipitation (Fig. 4). This was related to the different spatial distribution of precipitation and river observation stations (coastal/continental) and also to hydrological processes. For example, although some GNIR stations at high latitudes (e.g. Lena, Ob, and Yenisei River stations, Russian Federation $\left(66.5-69.4^{\circ} \mathrm{N}\right)$ had seasonal $\delta^{18} \mathrm{O}$ amplitudes above average, other stations at similarly high latitudes (e.g. Mackenzie River and Yukon River, Alaska -67.4 and $61.9^{\circ} \mathrm{N}$, respectively) exhibited relatively small amplitudes or were below average. In summary, the average annual seasonal $\delta^{18} \mathrm{O}$ amplitude was $2.5 \%$ for rivers compared to $7.5 \%$ for precipitation (Fig. 4). More than half of the 235 evaluated GNIR stations had seasonal $\delta^{18} \mathrm{O}$ amplitudes below $2 \%$. Catchment size or river length did not correlate with the isotopic amplitude. This global diminished riverine seasonal response, in comparison to pre-

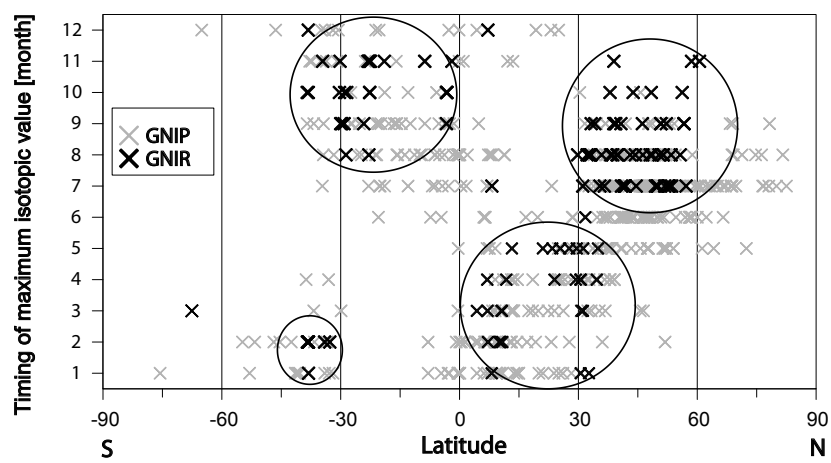

Figure 7. Isotopic seasonality of GNIR compared to GNIP stations. 567 GNIP and 218 GNIR stations with averaged (amount-weighted for GNIP) monthly $\delta^{18} \mathrm{O}$ values used for a direct comparison of latitude ( $x$ axis) and timing of maximum isotopic value ( $y$ axis), revealing "four world zones (large circles) of isotopic seasonality".

cipitation, showed that additional hydrological processes, catchment storage and natural reservoir mixing (e.g. lakes, groundwater) or man-made alterations modified the expected seasonal amplitude of $\delta^{18} \mathrm{O}$ in some rivers, as discussed above (Sect. 3.2). In any case, the seasonal amplitude of $\delta^{18} \mathrm{O}$ can clearly be used as a tracer of watershed hydrologic processes.

As noted, GNIR stations were clustered by a strong correlation between seasonal isotopic variation of $\delta^{18} \mathrm{O}$ in precipitation and river water as a function of latitude (groups B and C). Feng et al. (2009) previously evaluated seasonal variation of GNIP precipitation data based on the timing of maximum isotopic values in relation to latitude. A comparison of the GNIR river data to updated GNIP precipitation data (Fig. 7) affirmed their finding that there appears to be "four world zones of isotopic seasonality" which could be applied equally to rivers and precipitation. Furthermore, the latitudinal precipitation groupings around the Equator, as well as $\sim 30^{\circ} \mathrm{N}$ and $\mathrm{S}$, were observed in rivers and precipitation. This suggests that despite the fact that GNIR and GNIP data are point measurements and originate from different time periods, the main seasonal signals of precipitation are reasonably well preserved and visible in most river systems, even though the world's rivers are extensively modified by human impacts or impoundments.

While GNIP stations represent the isotopic composition of precipitation at a specific point location, GNIR stations integrate the cumulative precipitation input and hydrological processes of the upstream catchment. The application of CCRCWIP allowed for the comparison of modelled amountweighted isotopic precipitation inputs for upstream catchment precipitation $\left(\hat{\delta}^{18} \mathrm{O}_{\mathrm{P}}\right)$ to measured riverine (not discharge weighted) isotopic compositions at the GNIR observation stations $\left(\bar{\delta}^{18} \mathrm{O}_{\mathrm{R}}\right)$. The catchment-constrained model comparison revealed a strong correlation $\left(R^{2}=0.88\right)$ across the world catchments between amount-weighted mean pre- 
cipitation $\left(\hat{\delta}^{18} \mathrm{O}_{\mathrm{P}}\right)$ and river water discharge $\left(\bar{\delta}^{18} \mathrm{O}_{\mathrm{R}} ;\right.$ Fig. 8$)$. Of 119 GNIR river stations assessed, only 19 had $\bar{\delta}^{18} \mathrm{O}_{\mathrm{R}}$ and $\hat{\delta}^{18} \mathrm{O}_{\mathrm{P}}$ that deviated beyond the predicted CC-RCWIP model and analytical error $(1.3 \%$ ). Of these, in 15 stations the CC-RCWIP-predicted river discharge was more depleted in ${ }^{18} \mathrm{O}$ than was observed. The largest model versus observed mean difference was $4 \%$ for the Salinas River catchment in southern California, USA. For the river stations where CCRCWIP predicted $\delta^{18} \mathrm{O}$ values that were more negative than those observed, all were from arid regions such as western Africa, South Africa, and the southwestern USA. River water from two stations in Canada and Sweden located downstream of large lakes was also more enriched in ${ }^{18} \mathrm{O}$ than in the modelled precipitation for the upstream catchment. This analysis showed that a direct comparison of CC-RCWIPmodelled catchment inputs with measured riverine isotope data further helps to reveal important evaporation and hydrologic alterations within a catchment than can be accomplished by comparison with discrete GNIP stations or by mathematical models. GNIR stations for which CC-RCWIP predicted overly positive $\delta^{18} \mathrm{O}$ values included mainly the alpine basins, such as rivers within the Indus watershed, the Rhône River, Switzerland, or arctic watersheds such as the Lena River, Russia. This indicated that stored water sources from permafrost, snow, and glacier meltwater were comparatively important long-term contributors to the river runoff in these catchments. The importance of glacier meltwater in those river systems was also affirmed by non-isotopic studies (e.g. Immerzeel et al., 2010; Huss, 2011). Especially in ungauged catchments, but also in addition to quantitative studies, this method may be applied to evaluate glacier or permafrost contributions, or to observe winter/summer runoff ratios, as proposed by Bowen et al. (2011).

Finally, the CC-RCWIP-modelled seasonal amplitude of $\hat{\delta}^{18} \mathrm{O}_{\mathrm{P}}$ was not correlated to the seasonal amplitude of $\bar{\delta}^{18} \mathrm{O}_{\mathrm{R}}$, which confirmed the results from the direct comparison of GNIP and GNIR station data (Fig. 4).

\subsection{GNIR data to calibrate isotope precipitation model(s)}

To test the CC-RCWIP model as a tool to predict the expected isotopic composition of riverine discharges, the model was applied to regional and smaller water catchments that had an exceptionally high GNIR and GNIP station isotopic data density, compared to the overall global data set (Fig. 9). For this example, two major European river catchments (Rhine and upper Danube River, Switzerland, Germany, and Austria) were selected. The results showed that CC-RCWIP correctly predicted the $\delta^{18} \mathrm{O}$ isotopic composition of river discharge for all 12 GNIR river stations within a model and analytical error range of $1.3 \%$. The best fits (within 0.17-0.21\%o modelled vs. predicted deviation) were for four river stations located in peri-alpine and foreland subcatchments. The CC-RCWIP model predicted slightly

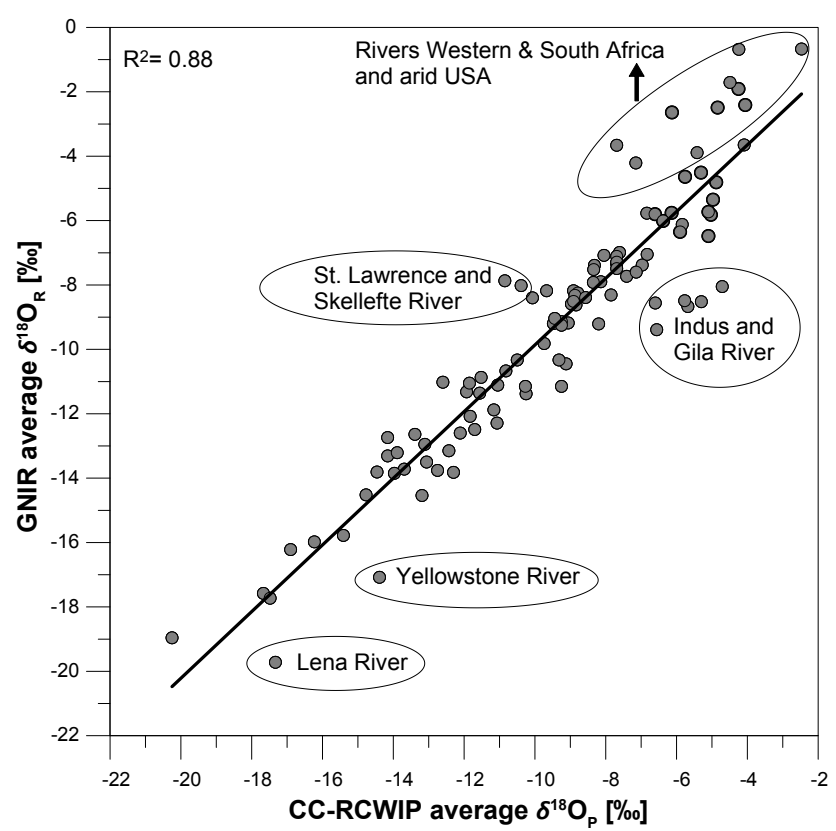

Figure 8. Comparison CC-RCWIP model and GNIR data. This figure depicted the comparison between the predicted amountweighted upstream catchment precipitation $\left(\hat{\delta}^{18} \mathrm{O}_{\mathrm{P}}\right)$ against measured (unweighted) isotopic composition at the GNIR river observation stations $\left(\bar{\delta}^{18} \mathrm{O}_{\mathrm{R}}\right)$.

negative $\delta^{18} \mathrm{O}$ values in the northern lowland rivers (except station Rhine-Lobith) and slightly positive $\delta^{18} \mathrm{O}$ values for most alpine headwaters and close after their confluence into main streams. This finding suggested isotope enrichment processes occurred due to evaporation in the lowlands but greater contributions of stored glacier melt-water to the alpine catchments. However, comparison of CC-RCWIP model prediction to riverine results may allow us to improve and validate the CC-RCWIP model calibration, since model versus observed differences can also arise due to the underestimation of local atmospheric circulation effects (e.g. influence of the Gulf Stream or ITCZ) by the model. Moreover, the CC-RCWIP grid is 10 arcmin, which means the model spatial resolution may smooth out extreme elevations in the terrain models, which would potentially bias the prediction towards positive $\delta^{18} \mathrm{O}$ values in alpine watersheds. Such effects were, for example, observed by Kern et al. (2014).

In general, the CC-RCWIP model results showed that averaged $\delta^{18} \mathrm{O}$ values in river water samples were strongly correlated with amount-averaged precipitation in the upstream catchment of a river station. This finding underscored that the average isotopic composition of river water reflected amountaveraged rainwater on a global scale, as was also observed regionally for the United States by Fekete et al. (2006) and Bowen et al. (2011). These model comparisons provided a comparative tool whereby isotopic deviations of rivers from average precipitation revealed natural or anthropogenic 


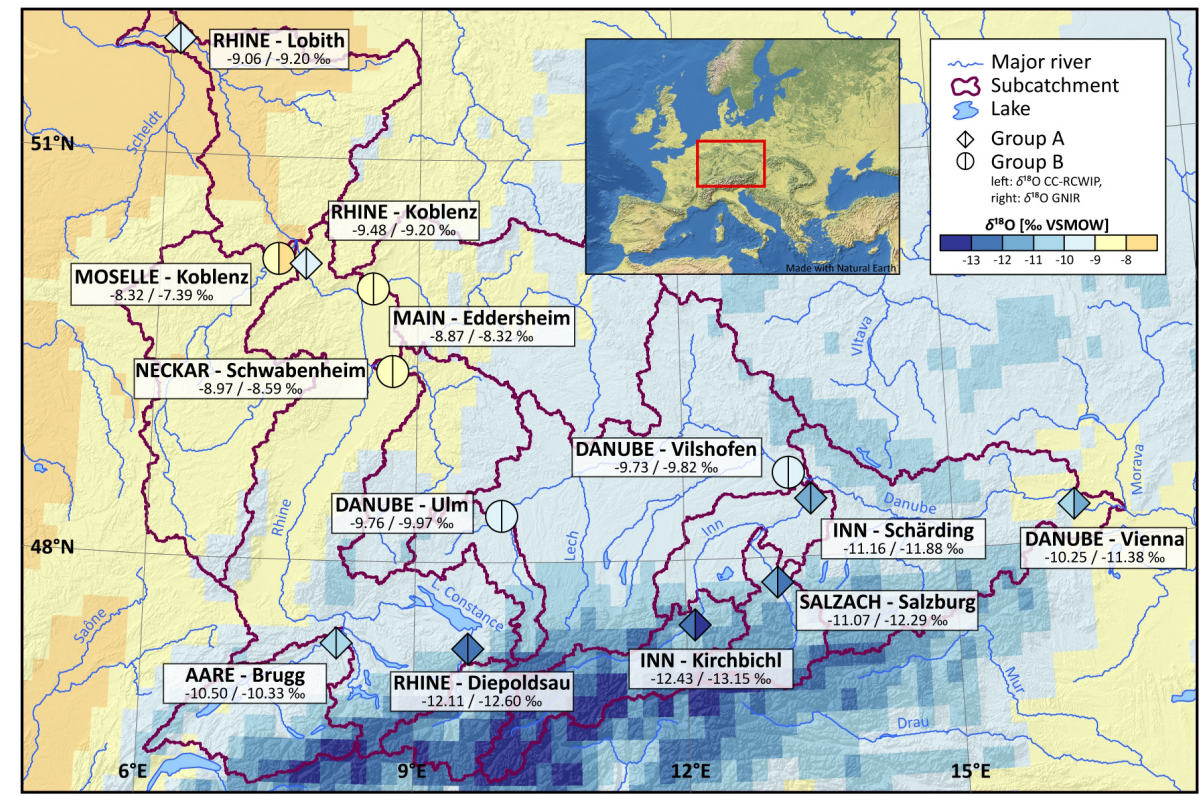

Figure 9. Catchment isoscapes for the Rhine and upper Danube River. This figure compared the modelled and amount-weighted isotopic input contributions of the entire upstream catchment precipitation to measured (unweighted) isotopic compositions at the GNIR river observation stations. Case study data were provided by the Helmholtz-Zentrum Munich, Germany; Environment Agency Austria; Federal Office for the Environment, Switzerland; and Centre for Isotope Research, University of Groningen, the Netherlands.

catchment impact effects. In general, a comparison of modelled and measured data may indicate the relative importance of stored watershed resources as ice, glaciers, old groundwater or, as demonstrated by Jasechko et al. (2013), important basin-scale evaporation and transpiration processes.

\section{Conclusions}

An evaluation of the IAEA GNIR database holdings of water isotopes in rivers revealed that seasonal variations in the stable isotopic composition of rivers were closely coupled to precipitation and to snowmelt water runoff on a global scale. This finding underscored the importance and advantages of combining long-term riverine isotope and precipitation data networks (GNIR and GNIP) to assess global and catchment water cycles as well as important environmental and human impacts. The results suggested that long-term observational time series in combination with modelling provide key scientific information for water managers and researchers to better study hydrological processes and impacts. Because the seasonal isotopic variability in river water was lower than that of precipitation, it can be stated that the isotopic composition of river water was likely more representative of the water used by plants and organisms within the watershed. The GNIR database may therefore become an additional valuable scientific resource not only for hydrology but also related disciplines focusing on isotope applications, e.g. for ecological and palaeoenvironmental studies. With the recent develop- ment of laser spectroscopy technologies for water stable isotope analysis, the approaches presented here are likely to be increasingly integrated within river quality, water quantity, and ecological studies. An increase in the number and spatial coverage of both GNIP and GNIR stations in areas of low spatial data coverage and the downscaling of the IAEA CCRCWIP model (or others) would also allow applying these methods to smaller local catchments in future.

The CC-RCWIP model presented in this study allows for an a priori prediction of the seasonal variability as well as the average isotopic composition of stable isotopes in rivers. This predictive model capacity will help to improve and inform existing and new river sampling strategies, to validate and interpret riverine isotope data, and aid in identifying important catchment processes. Hence, the IAEA promotes and supports long-term hydrological isotope observation networks and the application of isotope studies complemented with conventional hydrological, water quality, and ecological studies. We propose the GNIR database be further expanded using volunteer efforts to disseminate contributed and published time series of riverine isotope data, which can eventually include a far broader suite of isotopic variables involving not only water but a potential suite of water quality isotopic parameters such as dissolved constituents (e.g. ${ }^{13} \mathrm{C}$, DIC/DOC), nutrients (e.g. ${ }^{15} \mathrm{~N}$ and ${ }^{18} \mathrm{O}$ in $\mathrm{NO}_{3}$ ), radioisotopes (e.g. ${ }^{3} \mathrm{H}, \mathrm{U}$ ), and sediments (e.g. ${ }^{7} \mathrm{Li}$ ). 
Acknowledgements. The IAEA GNIR and GNIP programmes rely on voluntary partnerships with institutions and researchers for riverine and precipitation sample collections and isotopic analyses, as well as for the contribution of published and unpublished data to the GNIR and GNIP databases. The IAEA acknowledges all of the many individuals and institutions who contributed data over many years and thereby helped to establish and maintain these worldwide isotope hydrology observation networks. Funding for this assessment was provided by the International Atomic Energy Agency. The constructive comments of three reviewers are also greatly appreciated.

Edited by: N. Basu

\section{References}

Aggarwal, P. K., Araguás-Araguás, L. J., Groening, M., Kulkarni, K. M., Kurttas, T., Newman, B. D., and Vitvar, T.: Global hydrological isotope data and data networks, in: Isoscapes - Understanding movement, pattern, and process on Earth through isotope mapping, edited by: West, J. B., Boweb, G. J., Dawson, T. E., and Tu, K. P., Springer, Dordrecht, Heidelberg, London, New York, the Netherlands, 33-50, 2010.

Araguás-Araguás, L., Froehlich, K., and Rozanski, K.: Stable isotope composition of precipitation over southeast Asia, J. Geophys. Res.-Atmos., 103, 28721-28742, 1998.

Berman, E. S. F., Gupta, M., Gabrielli, C., Garland, T., Mc Donnell, J.: High-frequency field-deployable isotope analyzer for hydrological applications, Water Resour. Res., 45, 1-7, 2009.

Bowen, G. J. and Wilkinson, B.: Spatial distribution of $\delta^{18} \mathrm{O}$ in meteoric precipitation, Geology, 4, 315-318, 2001.

Bowen, G. J., Kenedy, C. D., Liu, Z., Stalker, J.: Water balance model for mean annual hydrogen and oxygen isotope distributions in surface waters of the contiguous United States, J. Geophys. Res., 116, 1-14, 2011.

Burgman, J. O., Eriksson, E., and Westman, F.: Oxygen-18 variation in river waters in Sweden, unpublished report, Uppsala University, Uppsala, 1981.

Buttle, J.: Isotope hydrograph separations and rapid delivery of preevent water from drainage basins, Prog. Phys. Geogr., 18, 16-41, 1994.

Craig, H.: Isotopic variations in meteoric waters, Science, 133, 1702-1702, 1961.

Dalai, T. K., Bhattacharya, S., and Krishnaswami, S.: Stable isotopes in the source waters of the Yamuna and its tributaries: seasonal and altitudinal variations and relation to major cations, Hydrol. Process., 16, 3345-3364, 2002.

Dansgaard, W.: Stable isotopes in precipitation, Tellus, 5, 436-468, 1964.

Darling, W. G. and Bath, A. H.: A stable isotope study of recharge processes in the English Chalk, J. Hydrol., 101, 31-46, 1988.

Dutton, A., Wilkinson, B. H., Welker, J. M., Bowen, G. J., and Lohmann, K. C.: Spatial distribution and seasonal variation in ${ }^{18} \mathrm{O} /{ }^{16} \mathrm{O}$ of modern precipitation and river water across the conterminous USA, Hydrol. Process., 19, 4121-4146, 2005.

Dynesius, M. and Nilsson, C.: Fragmentation and flow regulation of river systems in the northern third of the world, Science, 266, 753-762, 1994
Fekete, B. M., Gibson, J. J., Aggarwal, P., Vörösmarty, C. J.: Application of isotope tracers in continental scale hydrological modelling, J. Hydrol., 330, 444-456, 2006.

Feng, X., Faiia, A. M., and Posmentier, E. S.: Seasonality of isotopes in precipitation: A global perspective, J. Geophys. Res.Atmos., 114, 1-13, 2009.

Ferguson, P. R., Weinrauch, N., Wassenaar, L. I., Mayer, B., and Veizer, J.: Isotope constraints on water, carbon, and heat fluxes from the northern Great Plains region of North America, Global Biogeochem. Cy., 21, 1-11, 2007.

Friedman, I., Smith, G. I., Gleason, J. D., Warden, A., and Harris, J. M.: Stable isotope composition of waters in southeastern California 1. Modern precipitation, J. Geophys. Res.-Atmos., 97, 5795-5812, 1992.

Gibson, J., Edwards, T., Birks, S., St Amour, N., Buhay, W., McEachern, P., Wolfe, B., and Peters, D.: Progress in isotope tracer hydrology in Canada, Hydrol. Process., 19, 303-327, 2005.

Gremillion, P. and Wanielista, M.: Effects of evaporative enrichment on the stable isotope hydrology of a central Florida (USA) river, Hydrol. Process., 14, 1465-1484, 2000.

Hélie, J. F. and Hillaire-Marcel, C.: Sources of particulate and dissolved organic carbon in the St Lawrence River: isotopic approach, Hydrol. Process., 20, 1945-1959, 2006.

Huss, M.: Present and future contribution of glacier storage change to runoff from macroscale drainage basins in Europe, Water Resour. Res., 74, 1-14, 2011.

IAEA/WMO: Global Network of Isotopes in Precipitation. The GNIP Database, http://www.iaea.org/water, last access: 17 March 2015.

ICOLD - International Commission On Large Dams: http://www. icold-cigb.org/GB/World_register/generalsynthesis.asp, last access: 16 March 2015.

Immerzeel, W. W., Van Beel, L. P. H., and Bierkens, M. F. P.: Climate change will affect the Asian water towers, Science, 328 , 1382-1385, 2010.

Jasechko, S., Sharp, Z. D., Gibson, J. J., Birks, S. J., Yi, Y., and Fawcett, P. J.: Terrestrial water fluxes dominated by transpiration, Nature, 496, 347-350, 2013.

Kattan, Z.: Chemical and isotopic compositions of the Euphrates River water, Syria, in: Monitoring isotopes in rivers: Creation of the Global Network of Isotopes in Rivers (GNIR), IAEATECDOC-1673, Vienna, 2012.

Kendall, C. and Coplen, T. B.: Distribution of oxygen-18 and deuterium in river waters across the United States, Hydrol. Process., 15, 1363-1393, 2001.

Kendall, C. and McDonnell, J. J. (Eds.): Isotope tracers in catchment hydrology, Elsevier Science B. V., Amsterdam, the Netherlands, 1998.

Kendall, C., Young, M. B., and Silva, S. R.: Applications of stable isotopes for regional to national scale water quality monitoring programs, in: Isoscapes: Understanding movement, pattern, and process on Earth through isotope mapping, edited by: West, J. B., Bowen, G. J., Dawson, T. E., and Tu, K. P., Springer, Dordrecht, Heidelberg, London, New York, 2010.

Kern, Z., Kohán, B., and Leuenberger, M.: Precipitation isoscape of high reliefs: interpolation scheme designed and tested for monthly resolved precipitation oxygen isotope records 
of an Alpine domain, Atmos. Chem. Phys., 14, 1897-1907, doi:10.5194/acp-14-1897-2014, 2014.

Koeniger, P., Leibundgut, C., and Stichler, W.: Spatial and temporal characterisation of stable isotopes in river water as indicators of groundwater contribution and confirmation of modelling results; a study of the Weser River, Germany, Isot. Environ. Healt. S., 45, 289-302, 2009.

Lambs, L.: Correlation of conductivity and stable isotope ${ }^{18} \mathrm{O}$ for the assessment of water origin in river system, Chem. Geol., 164, 161-170, 2000.

Lambs, L.: Interactions between groundwater and surface water at river banks and the confluence of rivers, J. Hydrol., 288, 312326, 2004

Lambs, L., Balakrishna, K., Brunet, F., and Probst, J. L.: Oxygen and hydrogen isotopic composition of major Indian rivers: a first global assessment, Hydrol. Process., 19, 3345-3355, 2005.

Landwehr, J. M. and Coplen, T. B.: Line-conditioned excess: a new method for characterizing stable hydrogen and oxygen isotope ratios in hydrologic systems, IAEA-CSP-26, International Conference on Isotopes in Environmental Studies, Aquatic Forum 2004, Monte Carlo, Monaco, 2006.

Liu, Y., Fan, N., An, S., Bai, X., Liu, F., Xu, Z., Wang, Z., and Liu, S.: Characteristics of water isotopes and hydrograph separation during the wet season in the Heishui River, China, J. Hydrol., 353, 314-321, 2008.

Longinelli, A. and Edmond, J.: Isotope geochemistry of the Amazon basin: a reconnaissance, J. Geophys. Res.-Oceans, 88, $3703-$ 3717, 1983.

Maloszewski, P., Rauert, W., Trimborn, P., Herrmann, A., and Rau, R.: Isotope hydrological study of mean transit times in an alpine basin (Wimbachtal, Germany), J. Hydrol., 140, 343-360, 1992.

McDonnell, J., Bonell, M., Stewart, M., and Pearce, A.: Deuterium variations in storm rainfall: Implications for stream hydrograph separation, Water Resour. Res., 26, 455-458, 1990.

Meier, C., Knoche, M., Merz, R., and Weise, S. M.: Stable isotopes in river waters in the Tajik Pamirs: regional and temporal characteristics, Isot. Environ. Health S., 49, 542-554, 2013.

Michel, R. L., Aggarwal, P., Araguás-Araguás, L. J., Kurttas, T., Newman, B. D., and Vitvar, T.: A simplified approach to analysing historical and recent tritium data in surface waters, Hydrol. Process., 29, 572-578, 2014.

Mook, W. G.: The oxygen-18 content of rivers, Mitt. Geol.-Paläont. Inst. Univ. Hamburg, SCOPE/UNEP Sonderband, 52, 565-570, 1982.

Ogrinc, N., Kanduč, T., Stichler, W., and Vreča, P.: Spatial and seasonal variations in $\delta^{18} \mathrm{O}$ and $\delta \mathrm{D}$ values in the River Sava in Slovenia, J. Hydrol., 359, 303-312, 2008.

Oki, T. and Kanae, S.: Global Hydrological Cycles and World Water Resources, Science, 313, 1068-1072, 2006.

Panarello, H. O. and Dapeña, C.: Large scale meterolocical phenomena, ENSO and ITCZ, define the Paraná River isotope composition, J. Hydrol., 365, 105-112, 2009.

Pawellek, F., Frauenstein, F., and Veizer, J.: Hydrochemistry and isotope geochemistry of the upper Danube River, Geochim. Cosmochim. Acta, 66, 3839-3853, 2002.

Ramesh, R. and Sarin, M.: Stable isotope study of the Ganga (Ganges) river system, J. Hydrol., 139, 49-62, 1992.

Rank, D., Adler, A., Araguás Araguás, L., Froehlich, K., Rozanki, K., and Stichler, W.: Hydrological parameters and climatic sig- nals derived from long-term tritium and stable isotope time series of the River Danube, Isotope Techniques in the Study of Environmental Change, IAEA-SM-349, International Atomic Energy Agency, Vienna, 191-205, 1998.

Rank, D., Wyhlidal, S., Schott, K., Jung, M., Heiss, G., and Tudor, M.: A 50 years' isotope record of the Danube River water and its relevance for hydrological, climatological and environmental research, Acta. Zool. Bulg., 7, 109-115, 2014.

Rock, L. and Mayer, B.: Isotope hydrology of the Oldman River basin, southern Alberta, Canada, Hydrol. Process., 21, 33013315, 2007.

Rozanski, K., Sonntag, C., and Münnich, K. O.: Factors controlling stable isotope composition of European precipitation, Tellus, 34, 142-150, 1982.

Rozanski, K., Araguás-Araguás, L., and Gonfiantini, R.: Isotopic patterns in modern global precipitation, in: Climate Change in Continental Isotopic Records, edited by: Swart, P. K., Lohman, K. C., McKenzie, J., and Savin, S., Geophysical Monograph 78, American Geophysical Union, Washington, D.C., 1993.

Rozanski, K., Araguás-Araguás, L., and Gonfiantini, R.: Isotope patterns of precipitation in the East African Region, in: The Limnology, Climatology and Paleoclimatology of the East African Lakes, edited by: Johnson, T. C. Odada, E. O., and Johnson, C., Gordon and Breach, Amsterdam, 79-93, 1996.

Schotterer, U.: Wasserisotope in der Schweiz, Neue Ergebnisse und Erfahrungen aus dem nationalen Messnetz ISOT, Wasser, 12, 1073-1081, 2010.

Simpson, H. and Herczeg, A.: Stable isotopes as an indicator of evaporation in the River Murray, Australia, Water Resour. Res., 27, 1925-1935, 1991.

Sklash, M. G.: Environmental isotope studies of storm and snowmelt runoff generation, in: Process Studies in Hillslope Hydrology, edited by: Anderson, M. G. and Burt, T. P., John Wiley and Sons, Chichester, UK, 401-435, 1990.

Stumpp, C., Maloszewski, P., and Stichler, W.: Analysis of longterm stable isotopic composition in German precipitation and rivers, International Symposium on Isotope Hydrology: Revisiting Foundations and Exploring Frontiers, Proceedings of a Symposium, Book of extended Synopses, Poster Session 3, 114, Vienna, 11-15 May 2015.

Talma, S., Lorentz, S., and Woodborne, S.: South African contribution to the rivers CRP, in: Monitoring isotopes in rivers: Creation of the Global Network of Isotopes in Rivers (GNIR), IAEATECDOC-1673, IAEA, Vienna, 2012.

Taylor, S., Feng, X., Williams, M., and McNamara, J.: How isotopic fractionation of snowmelt affects hydrograph separation, Hydrol. Process., 16, 3683-3690, 2002.

Telmer, K. and Veizer, J.: Isotopic constraints on the transpiration, evaporation, energy, and gross primary production budgets of a large boreal watershed: Ottawa River basin, Canada, Global Biogeochem. Cy., 14, 149-165, 2000.

Terzer, S., Wassenaar, L. I., Araguás-Araguás, L. J., and Aggarwal, P. K.: Global isoscapes for $\delta^{18} \mathrm{O}$ and $\delta^{2} \mathrm{H}$ in precipitation: improved prediction using regionalized climatic regression models, Hydrol. Earth Syst. Sci., 17, 4713-4728, doi:10.5194/hess-174713-2013, 2013.

Vitvar, T., Aggarwal, P. K., and Herczeg, A. L.: Global network is launched to monitor isotopes in rivers, EOS Trans. Am. Geophys. Un., 88, 325-326, 2007. 
Vörösmarty, C. J., McIntyre, P., Gessner, M. O., Dudgeon, D., Prusevich, A., Green, P., Glidden, S., Bunn, S. E., Sullivan, C. A., and Liermann, C. R.: Global threats to human water security and river biodiversity, Nature, 467, 555-561, 2010.

Winston, W. and Criss, R.: Oxygen isotope and geochemical variations in the Missouri River, Environ. Geol., 43, 546-556, 2003.

Wyhlidal, S., Rank, D., Schott, K., Heiss, G., and Goetz, J.: Analysis of isotopic signals in the Danube River water at Tulln, Austria, based on daily grab samples in 2012, Isot. Environ. Healt. S., 50, 448-460, 2014
Yang, C., Telmer, K., and Veizer, J.: Chemical dynamics of the St. Lawrence River System, Geochim. Cosmochim. Acta, 60, 851-866, 1996.

Yi, Y., Gibson, J. J., Hélie, J.-F., and Dick, T. A.: Synoptic and timeseries stable isotope surveys of the Mackenzie River from Great Slave Lake to the Arctic Ocean, 2003 to 2006, J. Hydrol., 383, 223-232, 2010.

Yoshimura, K., Oki, T., Ohte, N., and Kanae, S.: A quantitative analysis of short-term ${ }^{18} \mathrm{O}$ variability with a Rayleigh-type isotope circulation model, J. Geophys. Res.-Atmos., 108, 1-15, 2003. 